\title{
Temporal and Spatial Variation of Nutrient Leaching from Agricultural Land in Latvia: Long Term Trends in Retention and Nutrient Loss in a Drainage and Small Catchment Scale
}

\author{
Viesturs Jansons ${ }^{1}$, Ainis Lagzdins, Laima Berzina ${ }^{3}$, Ritvars Sudars ${ }^{4}$, Kaspars Abramenko ${ }^{5}$, ${ }^{1-5}$ Latvia University of \\ Agriculture
}

\begin{abstract}
Agricultural run-off monitoring and losses of nitrogen $(N)$, phosphorus $(P)$ from small $(60$ - 960 ha) catchments and drainage fields $(12-77$ ha) in Latvia were analyzed. The catchments represent areas with different agricultural production intensity, landscape, soils and climate. Results from the long-term monitoring show (i) large differences in levels of losses between the catchments and fields with different farming intensity, (ii) large annual and interannual variability due to climate impact and soil conditions, (iii) few time trends in nutrient losses. These results are discussed in relation to pollution from non-point and point sources. Besides, these data demonstrate changes in agriculture driven by large-scale changes in land-use intensity. However, despite the increased implementation of mitigation methods by farmers, improvements in water quality at the catchment scale can take a long time. Long-term monitoring programmes to detect trends are required.
\end{abstract}

Keywords - Agriculture, monitoring, nutrients

\section{INTRODUCTION}

High nutrient levels in the surface waters can result from several agricultural pollution sources $[1,6,7,8,10,11,14$, and 26]. Non-point (diffuse) agricultural pollution or agricultural run-off is a major issue causing the pollution of surface water ecosystems in Latvia [12, 13, and 26]. The pollution of surface water due to nutrient input from diffuse sources is not easy to observe, measure and mitigate $[23,25$, and 26]. Non-point agricultural pollution occurs everywhere and always, and agro-environmental measures to reduce emissions in agriculture can provide limited results. A major cause of point source agricultural pollution comes from manure management arising from large-scale animal farming. Point source pollution is commonly associated with surface run-off from farm territories, manure storage, leakage from manure and urine reservoirs and other sources of poor manure management practices [1, 7, 9, and 24]. Therefore, in an assessment of agricultural run-off, it is crucial to be able to estimate the impact of animal farming and diffuse pollution on water quality by an apportionment of both agricultural pollution sources from the other types of pollution. In order to comply with EU regulations e.g., Nitrate Directive (ND) [22] and Water Framework Directive [3], it is important to understand the effect of the leaching of nitrates and other plant nutrients on eutrophication phenomenon. Monitoring of water pollution by agricultural run-off in Latvia has been implemented by the Department of Water Management and Environmental Engineering of Latvia University of Agriculture since 1994 [12, 15].

\section{MATERIAL AND METHODS}

\section{A. Monitoring of diffuse agricultural pollution}

An assessment of diffuse agricultural pollution has been implemented in three monitoring stations and four sampling points (Fig. 1). Diffuse pollution monitoring stations are placed in three small catchments (river basins $<10 \mathrm{~km} 2$ ). The Bērze, Mellupīte and Vienziemīte sites are located in different parts of Latvia and represent regions with different climate, soil, slopes, crops and farming intensity $[8,10,14]$. There are no another non-agricultural pollution sources located in these catchments. The soils at the monitoring sites are imperfectly to poorly drained. Most of the agricultural land in the small catchments is drained with tile drains (depth $1.1-1.3 \mathrm{~m}$, spacing between drains $10-32 \mathrm{~m}$ ).

However, monitoring of agricultural run-off in regions with humid climate is performed at several geographical scales. Nutrient losses from arable land might be measured at a drainage field level. Field scale run-off represents a combined effect on the water quality from farming practice, crop rotation, application of fertilizers, etc.

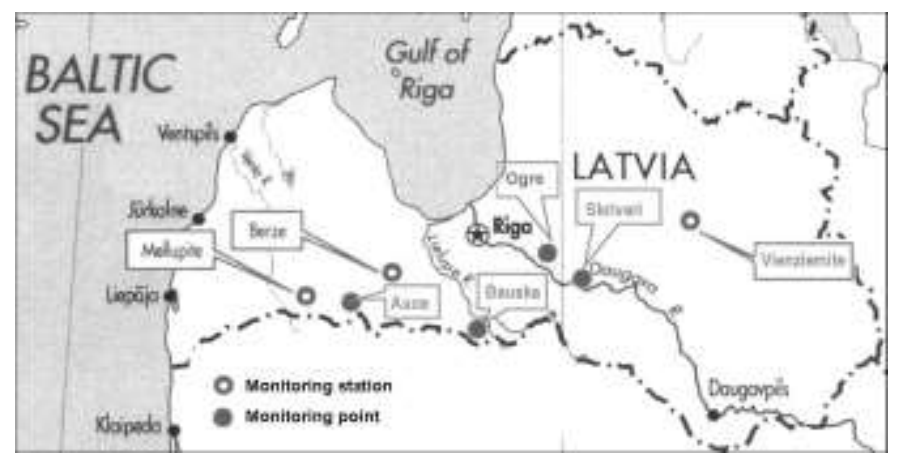

Fig. 1. Agricultural pollution monitoring stations and monitoring points in Latvia. 
The integrated influence on nutrient run-off of variations in farming practices, erosion, soil and topography within the small drainage basin (catchment) might be studied in a better way than on the field scale. In a small catchment scale, emission rates (loads) that can contribute to the nutrient enrichment of the surface water ecosystem can be examined. The method complies with the EU ND Monitoring Guidelines $[5,19,20]$, the internationally accepted practice $[26,27]$ and methods proposed in Latvia [19]. A description of the monitoring stations and monitoring points in Latvia can be found in Table 1. A monitoring station is a monitoring site equipped with a hydraulic structure to discharge measurements with data loggers. Permanent stations with structures and advanced equipment are used for diffuse pollution assessment in the Lielupe (Bērzes station), the Venta (Mellupites station) and the Gauja (Vienziemites station) river basin districts since 1994. For the apportionment of the point and non-point (diffuse) pollution sources, Skrīveri (since year 2000), Bauska (since year 1995) and Auce (since year 2004) monitoring points have been established on the small catchment scale. Monthly grab samples are collected at the monitoring points, however the discharge is modeled.

Specific hydraulic structures, i.e. Crump, V-shape Crump and combined profile weirs and data loggers for continuous and automatic measurements have been used in Bērze, Vienziemīte and Mellupīte monitoring stations. Data loggers measure the water level on the weir and calculate discharge continuously. Generally, automatic flow proportional sampling triggered by data logger was used in the stations. Based on a flow proportional sampling procedure, monthly composite water samples were collected. The grab sampling method used in the monitoring points have lower statistical power because the sampling frequency and method is less sufficient to cope with the high variability of water quality [5, 18 ] and the quick response to local meteorological conditions.

The parameters analysed included total $\mathrm{N}, \mathrm{NO}_{3}-\mathrm{N}, \mathrm{NH}_{4}-\mathrm{N}$, total $\mathrm{P}, \mathrm{PO}_{4}-\mathrm{P}$ and $\mathrm{pH}$. Water analyses were performed according to the standard methods.

The landscape of the Bērze site is flat lowland and $98 \%$ of the catchment soils are cultivated. Due to natural high soil fertility, winter wheat has become the main crop in the Bērze catchment. The share of arable crops increased up to 80-90\% during 1994 - 2010. Farmers are using modern equipment, and rather intensive technology for Latvia conditions. The Bērze catchment is characterised by relatively intensive crop production and modern technologies, as compared to the present average conditions in Latvia, e.g. a fertilizer application in few fields reached $170 \mathrm{~kg} \mathrm{~N}^{-1} \mathrm{year}^{-1}$ in 2010. However, by contrast, farms in the Vienziemite catchment apply low amounts of fertilizers (on average $4 \mathrm{~kg} \mathrm{~N} \mathrm{ha}^{-1}$ year $\left.{ }^{1}\right)$. The Vienziemite site is a typical example of low input farming and could be used as a reference site for the assessment of water quality in agricultural catchments. The Mellupìte catchment represents average farming conditions and could be considered typical for present agriculture in Latvia. Three large farms are using intensive agricultural technology, whereas a few farms produce only for self- consumption with low fertilization rates and without pesticides.

TABLE I

DESCRIPTION OF THE AGRICULTURAL POLLUTION MONITORING SITES (DIFFUSE POLLUTION)

\begin{tabular}{|c|c|c|c|c|}
\hline $\begin{array}{l}\text { Site, monitoring, } \\
\text { level for water } \\
\text { sampling }\end{array}$ & $\begin{array}{l}\text { Area, } \\
\text { ha }\end{array}$ & $\begin{array}{l}\% \\
\text { cultiv } \\
\text { ated }\end{array}$ & $\begin{array}{l}\text { Main soil } \\
\text { type * }\end{array}$ & $\begin{array}{l}\text { Description of } \\
\text { agriculture }\end{array}$ \\
\hline \multicolumn{5}{|l|}{ Monitoring stations } \\
\hline \multicolumn{5}{|l|}{$\begin{array}{l}\text { Vienziemīte, Cēsu } \\
\text { district }\end{array}$} \\
\hline Small catchment & 592 & 78 & Cambisol & $\begin{array}{l}\text { Low input } \\
\text { farming }\end{array}$ \\
\hline Drainage field & 67 & 100 & Sanay loam & $\begin{array}{l}\text { Low input } \\
\text { farming }\end{array}$ \\
\hline \multicolumn{5}{|l|}{$\begin{array}{l}\text { Mellupīte, Saldus } \\
\text { district }\end{array}$} \\
\hline Small catchment & 960 & 69 & $\begin{array}{l}\text { Stagnic } \\
\text { Luvisol }\end{array}$ & $\begin{array}{l}\text { Moderately } \\
\text { intensive }\end{array}$ \\
\hline Drainage field & 12 & 100 & $\begin{array}{l}\text { Loam, clay } \\
\text { loam }\end{array}$ & $\begin{array}{l}\text { Intensive } \\
\text { farming } \\
\text { Intensive grain } \\
\text { farming }\end{array}$ \\
\hline $\begin{array}{l}\text { Bērze, Dobeles } \\
\text { district }\end{array}$ & & & $\begin{array}{l}\text { Calcric } \\
\text { Cambisol }\end{array}$ & \\
\hline Small catchment & 368 & 98 & 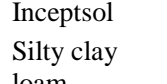 & $\begin{array}{l}\text { Intensive grain } \\
\text { farming }\end{array}$ \\
\hline Drainage field & 77 & 100 & loam & $\begin{array}{l}\text { Intensive grain } \\
\text { farming }\end{array}$ \\
\hline \multicolumn{5}{|l|}{ Monitoring points } \\
\hline $\begin{array}{l}\text { Vecauce, Dobeles } \\
\text { district }\end{array}$ & & & $\begin{array}{l}\text { Gleyic } \\
\text { Cambisol }\end{array}$ & Intensive grain \\
\hline Small catchment & 60 & 90 & Sandy loam & farming \\
\hline $\begin{array}{l}\text { Bauska, Bauskas } \\
\text { district. }\end{array}$ & & & $\begin{array}{l}\text { Chromic } \\
\text { Cambisol }\end{array}$ & Intensive \\
\hline Small catchment & 750 & 95 & Silt loam & $\begin{array}{l}\text { farming, mixed } \\
\text { crops }\end{array}$ \\
\hline $\begin{array}{l}\text { Skrīveri, } \\
\text { Aizkraukles }\end{array}$ & & & $\begin{array}{l}\text { Uutric } \\
\text { Podzoluvisol }\end{array}$ & \\
\hline $\begin{array}{l}\text { district } \\
\text { Small catchment }\end{array}$ & 890 & 40 & $\begin{array}{l}\text { Silty clay } \\
\text { loam }\end{array}$ & $\begin{array}{l}\text { Moderately } \\
\text { intensive } \\
\text { farming }\end{array}$ \\
\hline
\end{tabular}

* FAO soil classification

\section{B. Monitoring of the point source agricultural pollution}

Monitoring of the point source agricultural pollution in Latvia was implemented in three small catchments, where pollution from large livestock farms has an impact on water quality [1, 7, 9, and 24]. The Bauska, Vecauce and Ogre sites are characterized by large applications of animal manure (slurry). The catchments were previously a part of large state and collective farms that specialized in pig production. A description of the point source pollution monitoring sites is presented in Table 2.

The Vecauce (LLU Vecauce, "Pūpolu" farm) farm started pig production in 1990 and produces about $1000-2000$ pigs per year today. In the upper part of the Vecauce farm catchment (60 ha), forest and wetlands cover 5 ha $(9 \%) .30$ ha of the catchment area are used for slurry application. On average, $200 \mathrm{~m} 3$ slurry per ha and year have been applied on 
winter grains during the vegetation seasons from 1995 2010. This application rate corresponds to a nutrient supply of approximately $180-360 \mathrm{~kg} \mathrm{~N} \mathrm{ha}^{-1}$ and 13-26 kg P ha ${ }^{-1}$. Previous experience demonstrated that the main principles of good agricultural practice are used in manure handling in the Vecauce farm.

The Bauska ("Strautu") farm was established in 1970 and reached full production (12 000 fattening pigs per year, $55000 \mathrm{~m}^{3}$ pig slurry per year) in 1976. Until 1987 tractordriven tankers were used for slurry application. In 1987 a slurry irrigation system (226 ha) was installed. Today the pig production is $8000-10000$ fattening pigs per year, but the slurry utilization area is only 50 hectares, due to changes in land use after privatization. Slurry has been applied on grassland fields throughout the whole year. On average 900 $\mathrm{m}^{3}$ of slurry has been applied per ha annually, representing a nutrient supply of approximately $630 \mathrm{~kg}$ total $\mathrm{N} \mathrm{ha}^{-1}$ and 80 $\mathrm{kg} \mathrm{P} \mathrm{ha}{ }^{-1}$ that does not meet the requirements of ND $(170 \mathrm{~kg}$
$\mathrm{N} \mathrm{ha}^{-1}$ ). Simultaneous grab sampling is performed downstream from the farm and in the upstream part of the catchment to assess the impact of point agricultural pollution.

The Ogre farm was completely closed after 15 years of production in 1992. The farm produced about 30000 pigs per year prior to its closure. Earth lagoons were used for slurry storage and still remain full of slurry at this farm. Soil in the surrounding territory of the Ogre farm is still polluted due to improper manure handling during 1977 - 1991. Slurry was applied by tractor tankers and sprinkler irrigation on 240 ha of land and several leakage accidents took place from the lagoons. Old pollution still has an impact on water quality in that catchment [1].

The measurements in Bauska, Ogre and Vecauce were based on manual water sampling at regular intervals (once per month) since year 1995.

TABLE II

DESCRIPTION OF THE AGRICULTURAL POLLUTION MONITORING SITES (POINT SOURCE POLLUTION)

\begin{tabular}{lllll}
\hline Site, monitoring level & $\begin{array}{l}\text { Area, } \\
\text { ha }\end{array}$ & $\begin{array}{l}\text { Cultivated } \\
\text { land, } \%\end{array}$ & Soil & Description of agriculture \\
\hline Auce, monitoring point & & & & \\
\hline $\begin{array}{l}\text { Small catchment in slurry } \\
\text { application area }\end{array}$ & 60 & 90 & Sandy loam & $\begin{array}{l}\text { Intensive grain farming, arable land } 80 \% \text {. Slurry } \\
\text { application on 30 ha within catchment. }\end{array}$ \\
\hline Bauska monitoring point & & & Silt loam & $\begin{array}{l}\text { Intensive farming, mixed crops. Slurry dumping site on } \\
50 \text { ha and pig farm within catchment. }\end{array}$ \\
\hline $\begin{array}{l}\text { Small catchment in slurry } \\
\text { application area including pig } \\
\text { farm }\end{array}$ & 800 & 95 & & Silty clay loam, \\
\hline Ogre monitoring point & & & $\begin{array}{l}\text { Moderately intensive farming, old slurry lagoons and } \\
\text { polluted territory of former pig farm within catchment, } \\
\text { farm closed in 1992. }\end{array}$ \\
\hline $\begin{array}{l}\text { Small catchment in slurry } \\
\text { application area including pig } \\
\text { farm }\end{array}$ & 300 & 25 & &
\end{tabular}

\section{Climate and Hydrology}

Latvia is situated in a humid and moderately mild climatic region where rainfall exceeds evaporation, resulting in percolation losses from the soil during spring and autumn. The annual precipitation in Latvia is $550-750 \mathrm{~mm}$ per year. A wide range of precipitation from 1994 - 2010 was characterized by dry years in 1996, 2006, normal years in 1994, 2004, and wet years in 2007 and 2010.

Similarly, maximum and minimum extremes were observed in the water discharge (Fig. 2) in the monitoring catchments during the period of 1994 - 2010. The year 2006 was the driest since 1974 (run-off $116 \mathrm{~mm}$ per year in the Vienziemìte site) and 1995 was a wet year with the run-off $467 \mathrm{~mm}$ per year at the same Vienziemite monitoring site. The wide range of climatic and hydro meteorological conditions at the Bērze and Mellupīte sites was illustrated by a run-off ranging from less than $100 \mathrm{~mm}$ to more than 300 $\mathrm{mm}[2,3$, and 26].

To obtain values for the runoff from the manure utilization points and the Mellupite catchment area, the METQ96 model was used. The model contains sub routines for snow accumulation and ablation, soil moisture accounting, groundwater and capillary fringe accounting, runoff generation and a simple routing procedure. Input parameters to the model are daily values for temperature, precipitation and the vapor pressure deficits which are standard meteorological data that are available in meteorological stations in Latvia. A detailed description of the model is given by A. Zīverts et al. [16]. 


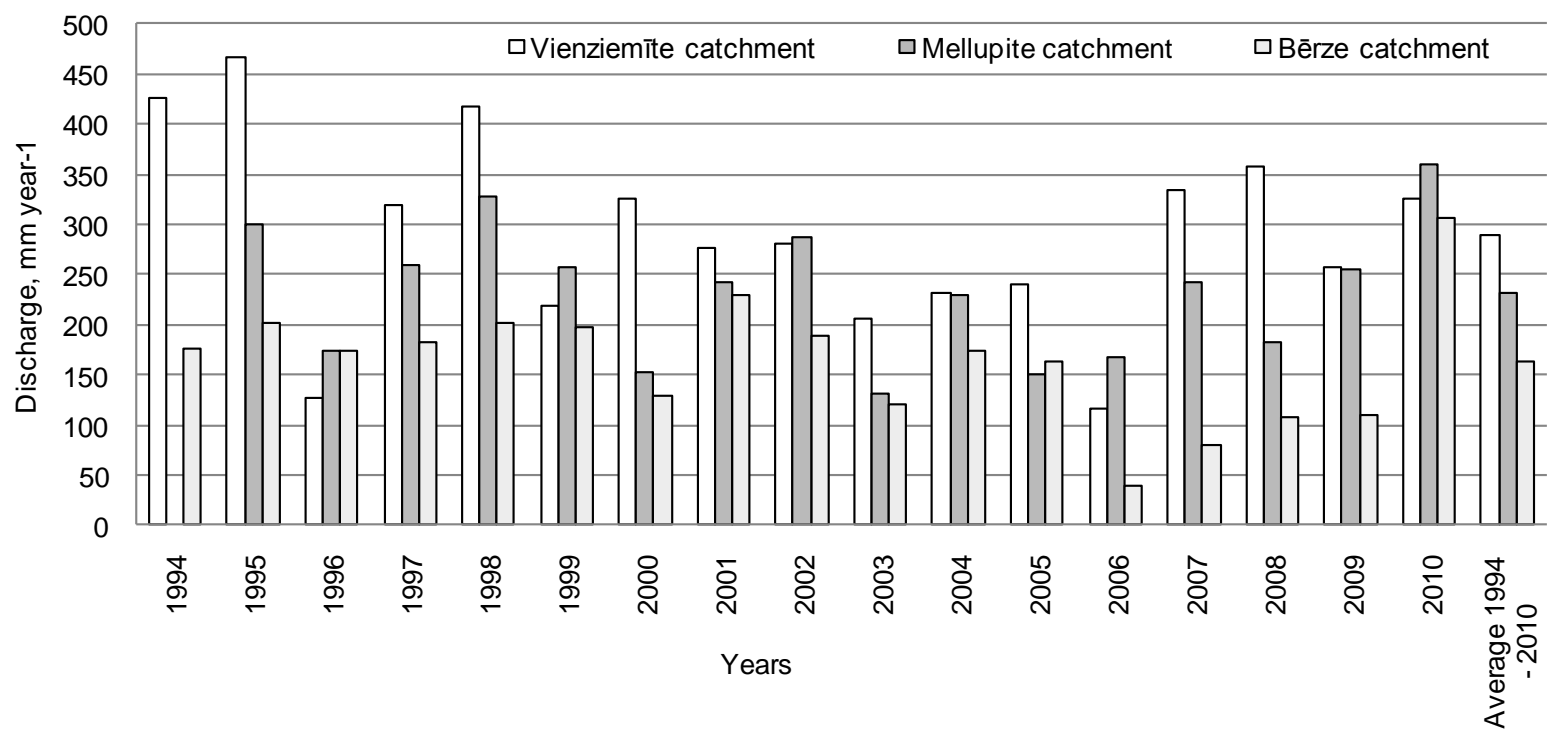

Fig. 2. Water discharge in small catchment scale in the monitoring station sites.

\section{Nutrient run-off}

Nutrient leakage was calculated by multiplying the nutrient $\left(\mathrm{N}_{\text {tot }}, \mathrm{P}_{\text {tot }}\right)$ concentrations of the composite water samples with the total volume of water discharged during the corresponding water sampling period. The research in the small catchment scale demonstrates that the rapid response of discharge due to rainfall or snowmelt and fast changes in water quality parameters caused nutrient enrichment on a local scale in small catchment or drainage field are observed more often than at the large river scale. Usually, during the flood period more frequent water sampling could be recommended, as mentioned in ND [17, 19, 22,].

In order to calculate of nutrient run-off for the corresponding measurement period, the daily nutrient concentrations $\left(\mathrm{C}_{\mathrm{i}}\right)$ are interpolated from monthly nutrient values [19].

$$
V=0,01 \sum C_{i} * Q_{i}
$$

where

$\mathrm{V}$ - nutrient run-off, $\mathrm{kg} \mathrm{ha}^{-1}$ year $^{-1}$;

$\mathrm{C}_{\mathrm{i}}$ - average daily concentrations, $\mathrm{mg} \mathrm{l}^{-1}$;

$\mathrm{Q}_{\mathrm{i}}$ - average water discharge, $\mathrm{mm}$.

Hourly and daily discharges $\left(Q_{i}\right)$ are calculated automatically by a data logger, where water level measurements are performed every 2 - 3 minutes. Moreover, the data logger calculates the volume of the water discharged over the hydraulic structure and after bypass of certain amount of water sends a signal to the water sampling pump. Our experience shows that the logger-triggered sampling frequency could be 10 - 15 subsamples per day. One water proportional composite sample consists of a large number of subsamples gathered during a period of one month, i.e., 12 water samples were collected, if there was discharge all year around.

\section{RESULTS AND DISCUSSION}

\section{A. Nutrient concentrations}

EU ND monitoring guidelines [5] for the implementation of Article 3.1 propose that long term (20 - 30 years) nitrate trends have been analyzed for:

- Yearly average values;

- Winter period values;

- Maximal concentrations of nitrates.

The guidelines [5] suggest that the presence of nitrate nitrogen $\left(\mathrm{NO}_{3}{ }^{-}-\mathrm{N}\right)$ during the winter period (October March) better describes the potential amount of available nitrogen resulting in eutrophication in summer. When analyzing nutrient impact during the vegetation season, it is more useful to measure the total nitrogen $\left(\mathrm{N}_{\text {tot }}\right)$.

However, EU Water directives and guidelines [4, 20, 21, 22] do not explain what values of nitrate concentrations should be used (e.g., average annual, winter or maximum peak nitrate) to compare the limit value for nitrates established by $\mathrm{ND}-50 \mathrm{mg} \mathrm{l}^{-1} \mathrm{NO}_{3}^{-}$or $11.3 \mathrm{mg} \mathrm{l}^{-1} \mathrm{NO}_{3}^{-}-\mathrm{N}[5,22]$. Therefore, the assessment of nitrate concentrations was performed for maximum peak $\mathrm{NO}_{3}{ }^{-}-\mathrm{N}$, winter concentrations of the $\mathrm{NO}_{3}{ }^{-}-\mathrm{N}$ and summer concentrations of the $\mathrm{N}_{\text {tot }}$.

\section{B. Nitrate concentrations}

Limit values of nitrate $\left(11.3 \mathrm{mg}^{-1}\right)$ established by the Directive were often exceeded in the small catchment and drainage run-off from fields with intensive farming in the Bērze monitoring site since the year 1996 (Fig. 3 and 4). Generally, drainage field run-off has higher nitrate concentrations and a higher risk that threshold values of ND could be exceeded. 
Surprisingly, high nitrate values in the Berrze drainage field run-off were found in November 2006, when drainage run-off appeared after the dry summer - autumn period. As shown in Fig. 3, the nitrate concentration may be extremely high. The VSIA "Centre for Agrochemical Research" has analyzed mineral nitrogen in several fields. Data of the soil mineral nitrogen, presented in, provide the information on soil leakage potential in the autumn of 2006 resulting in high concentrations when drainage run-off started in November. Run-off transported a considerable amount of nitrogen that was accumulated in the soil during the summer and early autumn due to the dry and hot weather conditions [13]. In addition, the soil had many cracks and macro pores. In the small catchment scale (Fig. 4), long-term concentration trends of different nitrogen compounds show an increase by 50 $90 \%$ during $1994-2010$.

Due to the extremely high nitrate values in $2006 / 2007$ in the drainage field scale (Fig. 3), trends are impossible to evaluate. However, summer $\mathrm{N}_{\text {tot }}$ concentration values increased by $20 \%$.

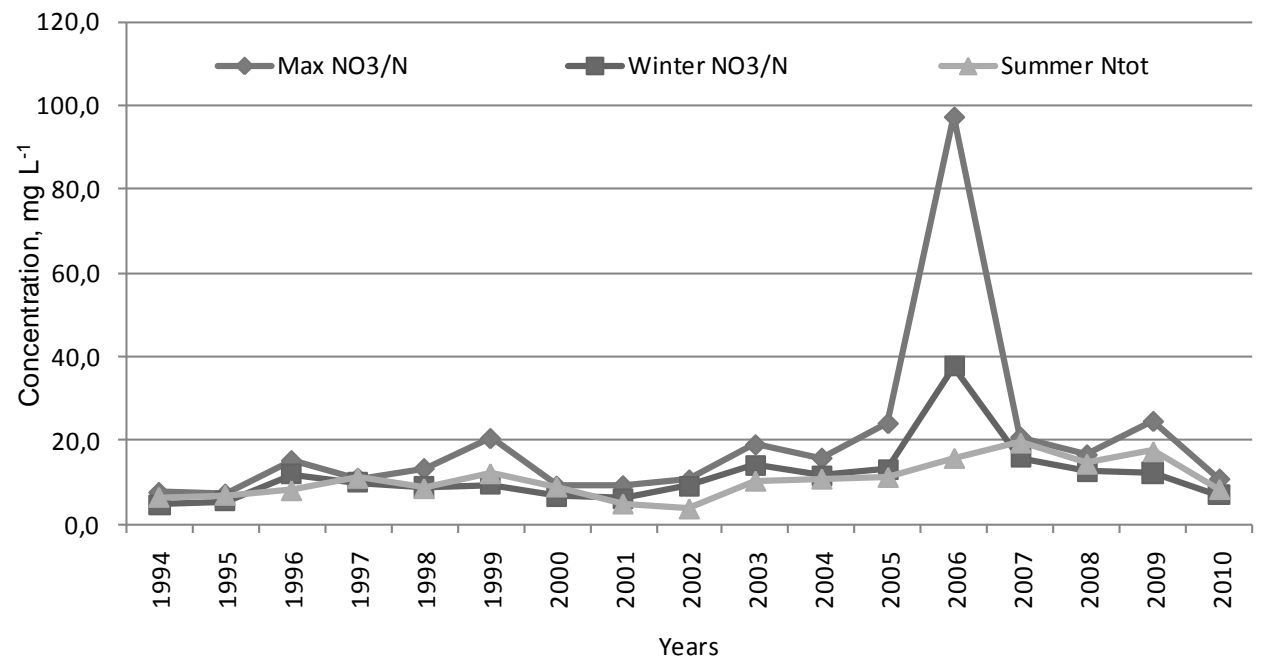

Fig. 3. Annual average nitrogen concentrations in drainage field run-off, Bērze monitoring station.

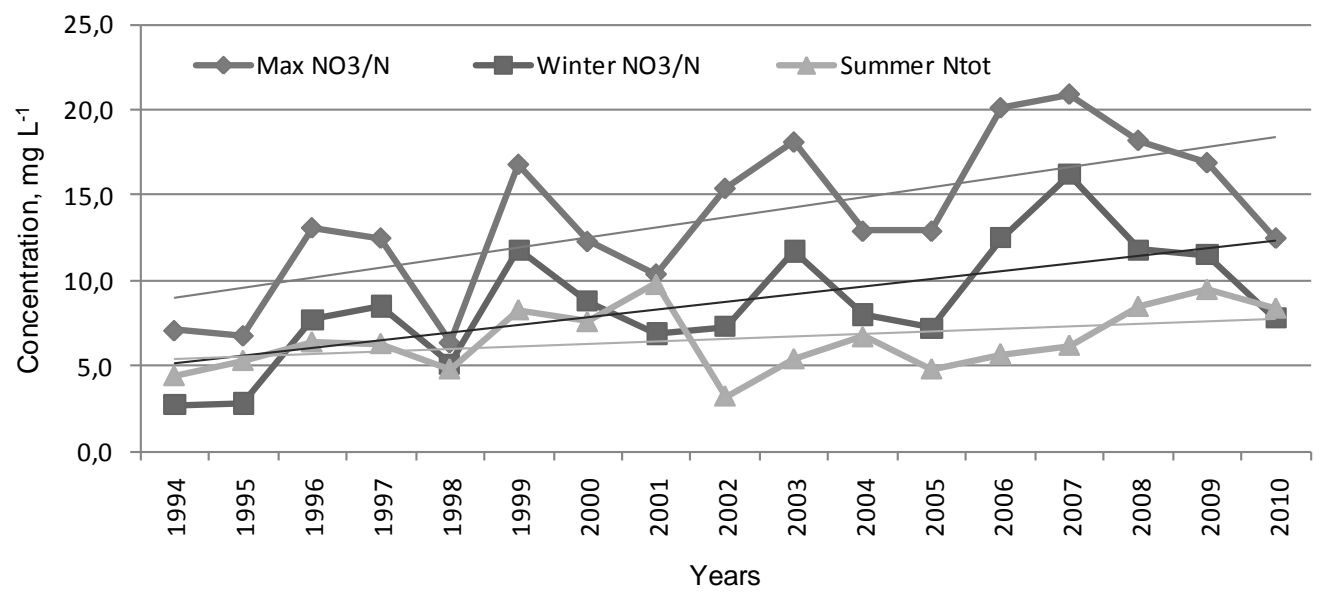

Fig. 4. Annual average nitrogen concentrations in small catchment run-off, Bērze monitoring station.

With regard to the Nitrate Directive, it should be noted that the limit values of nitrate $\left(11.3 \mathrm{mg} \mathrm{l}^{-1}\right)$ established by the Directive were exceeded in the drainage field of the Mellupite site during 2006 - 2008 (Fig. 5). Similarly to the Bērze site in that the field farmer used intensive technologies and farming methods. In the small catchment scale (Fig. 6) in the Mellupite site, the limit concentrations of nitrates were exceeded only during 2003. Both on the catchment and the field scale, longterm nitrate concentrations show an upward trend (Fig. 6). In the Vienziemite site, which could be used as a reference site with low input agriculture, both on the catchment and the drainage field scale, during the period of 1994 - 2010, nitrogen concentrations close to the limit values of ND were not determined. Annual average concentrations in plot and field scale have a relatively small difference (Fig. 7 and 8), which could be attributed to normal variation. Long-term trends show no significant increase or decrease of nitrogen compounds in the Vienziemite site during 1994 - 2010. 


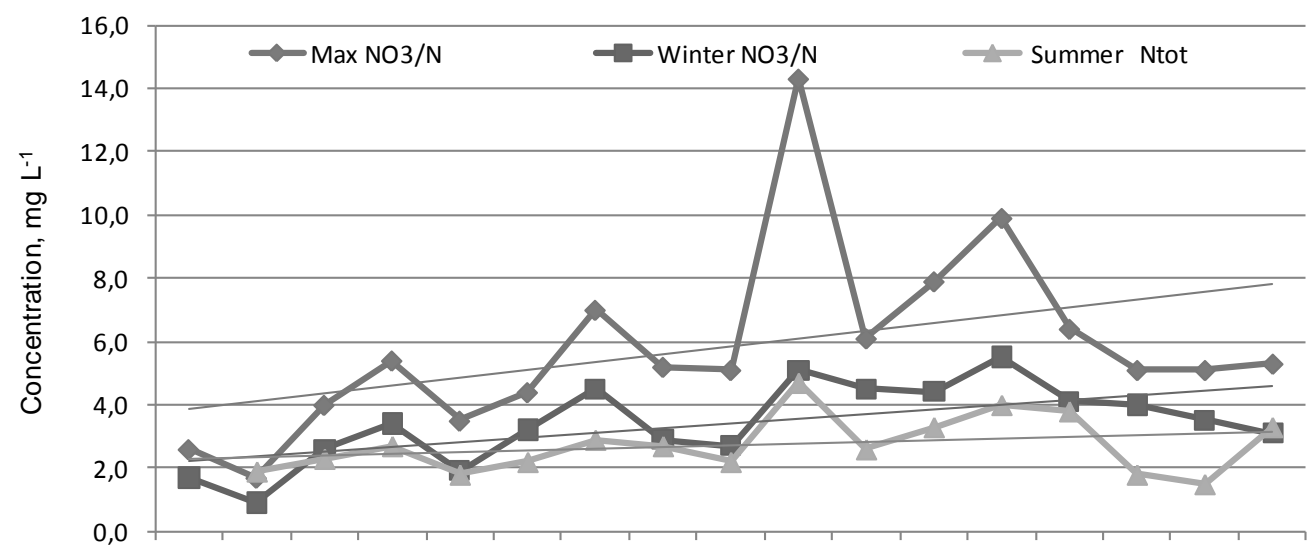

19941995199619971998199920002001200220032004200520062007200820092010

Years

Fig. 5. Annual average nitrogen concentrations, Mellupīte drainage field.

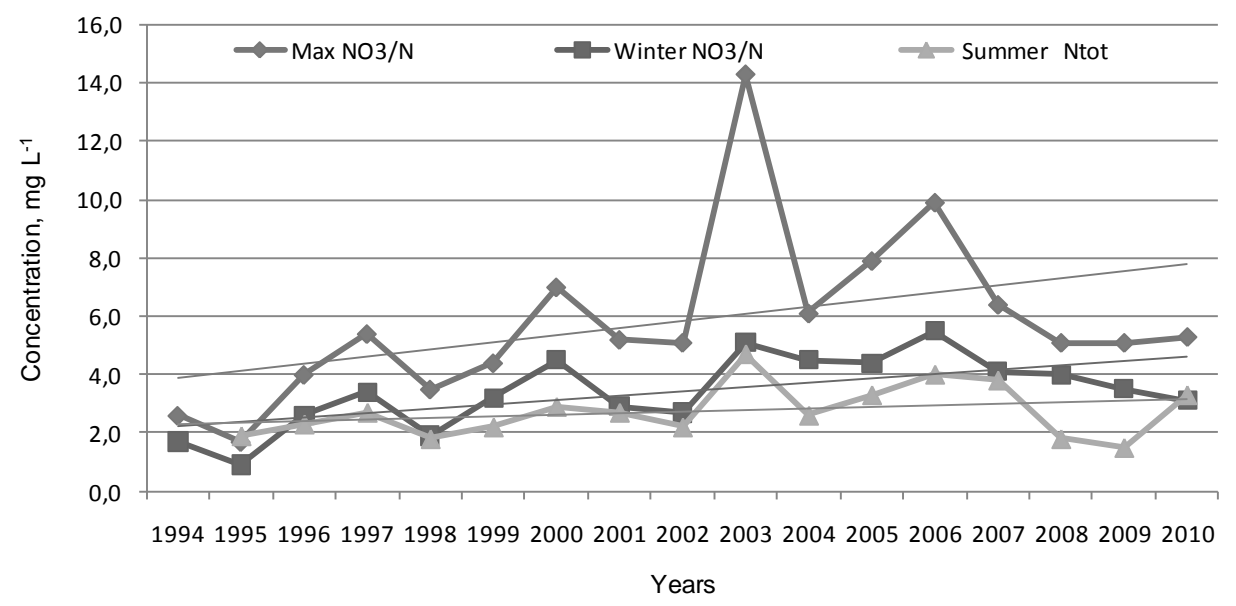

Fig. 6. Annual average nitrogen concentrations, Mellupīte small catchment.

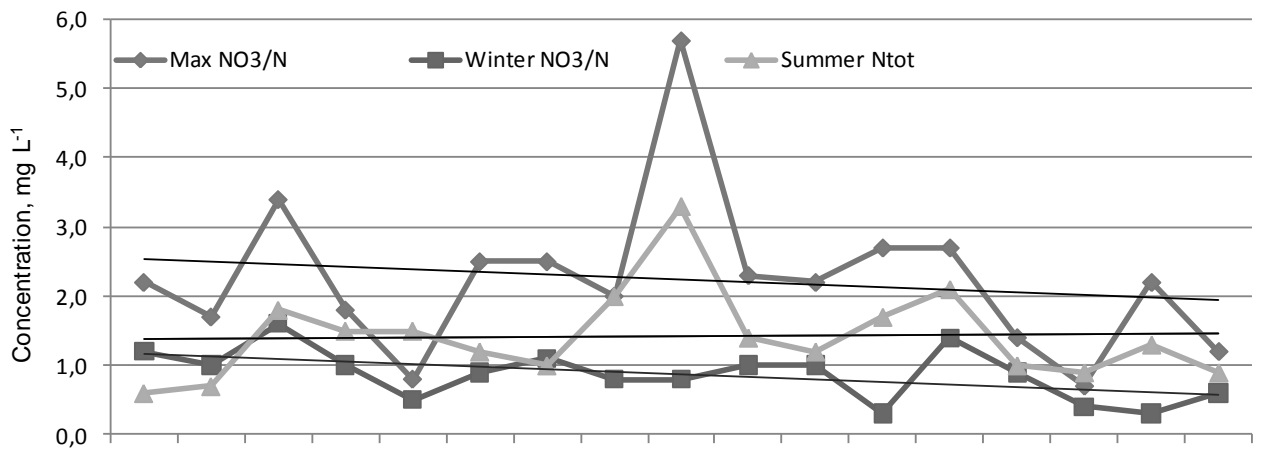

19941995199619971998199920002001200220032004200520062007200820092010 Years

Fig. 7. Annual average nitrogen concentrations, Vienziemīte field drainage. 


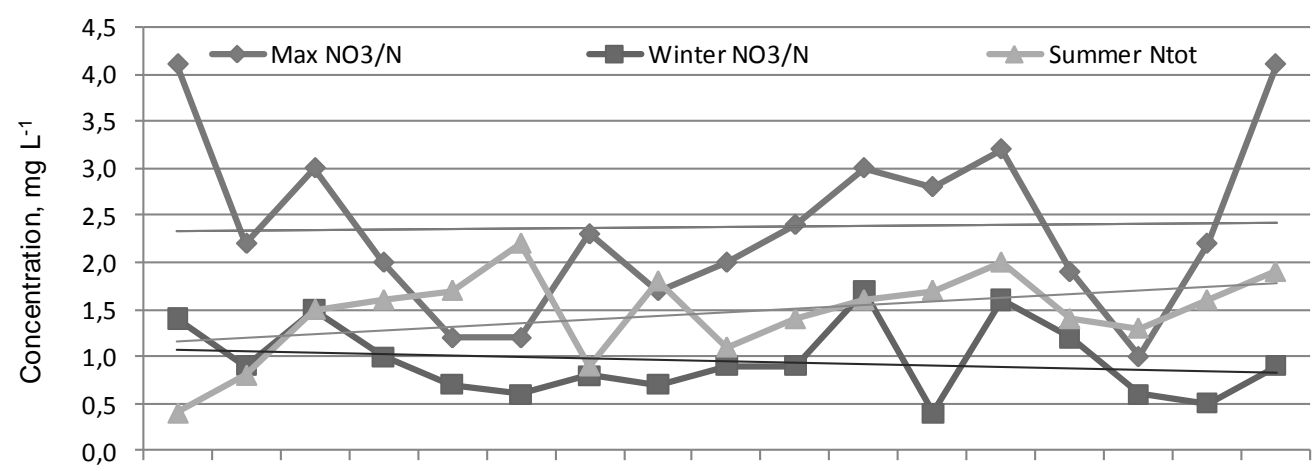

19941995199619971998199920002001200220032004200520062007200820092010

Years

Fig. 8. Annual average nitrogen concentrations, Vienziemīte small catchment.

\section{Nutrient run-off in the diffuse pollution monitoring sites}

Nutrient run-off from diffuse pollution monitoring sites is presented in Fig. 9, 10 and 11. Monitoring results have demonstrated the evident influence of water discharge on nutrient run-off. High precipitation rates determined continuous discharge on the small catchment scale during the wet years of 2007 and 2010. Even field drainage has a short period without discharge in June at the Bērze site. The results indicated that the highest nitrogen leakage was measured in the years 2007, 2008 and 2010. The research has shown that, despite high nitrogen concentrations in field drainage in the Bērze station, high nitrogen run-off was observed in the Mellupite site. This was accompanied by an increase in discharge in the Mellupite drainage systems. On the small catchment scale, relatively intensive farming in the Zemgale region (Bērze) contributed to a higher nutrient run-off (Table 3). Relatively low nutrient levels were measured in Vienziemìte, in the site with low input agriculture.
TABLE III

ANNUAL AVERAGE DISCHARGE AND NUTRIENT RUN-OFF FROM DIFUSSE POLUTION SOURCES

\begin{tabular}{|c|c|c|c|}
\hline Monitoring station & $\begin{array}{l}\text { Discharge, } \\
\text { mm }\end{array}$ & $\begin{array}{l}\text { Run-off } \\
N_{\text {tot, }} \text { kg/ha } \\
\text { year }\end{array}$ & $\begin{array}{l}\text { Run-off } \\
P_{\text {tot, }} \text { kg/ha } \\
\text { year }\end{array}$ \\
\hline \multicolumn{4}{|c|}{ Vienziemīte monitoring station } \\
\hline Small catchment, 592 ha & 290 & 5.6 & 0.11 \\
\hline Field drainage, 67 ha & 251 & 4.6 & 0.13 \\
\hline \multicolumn{4}{|c|}{ Mellupīte monitoring station } \\
\hline Small catchment, 960 ha & 233 & 10.2 & 0.12 \\
\hline Field drainage, 12 ha & 246 & 17.9 & 0.13 \\
\hline \multicolumn{4}{|l|}{ Bērze monitoring station } \\
\hline Small catchment, 368 ha & 164 & 14.6 & 0.34 \\
\hline Field drainage, 76 ha & 332 & 17.8 & 0.50 \\
\hline
\end{tabular}

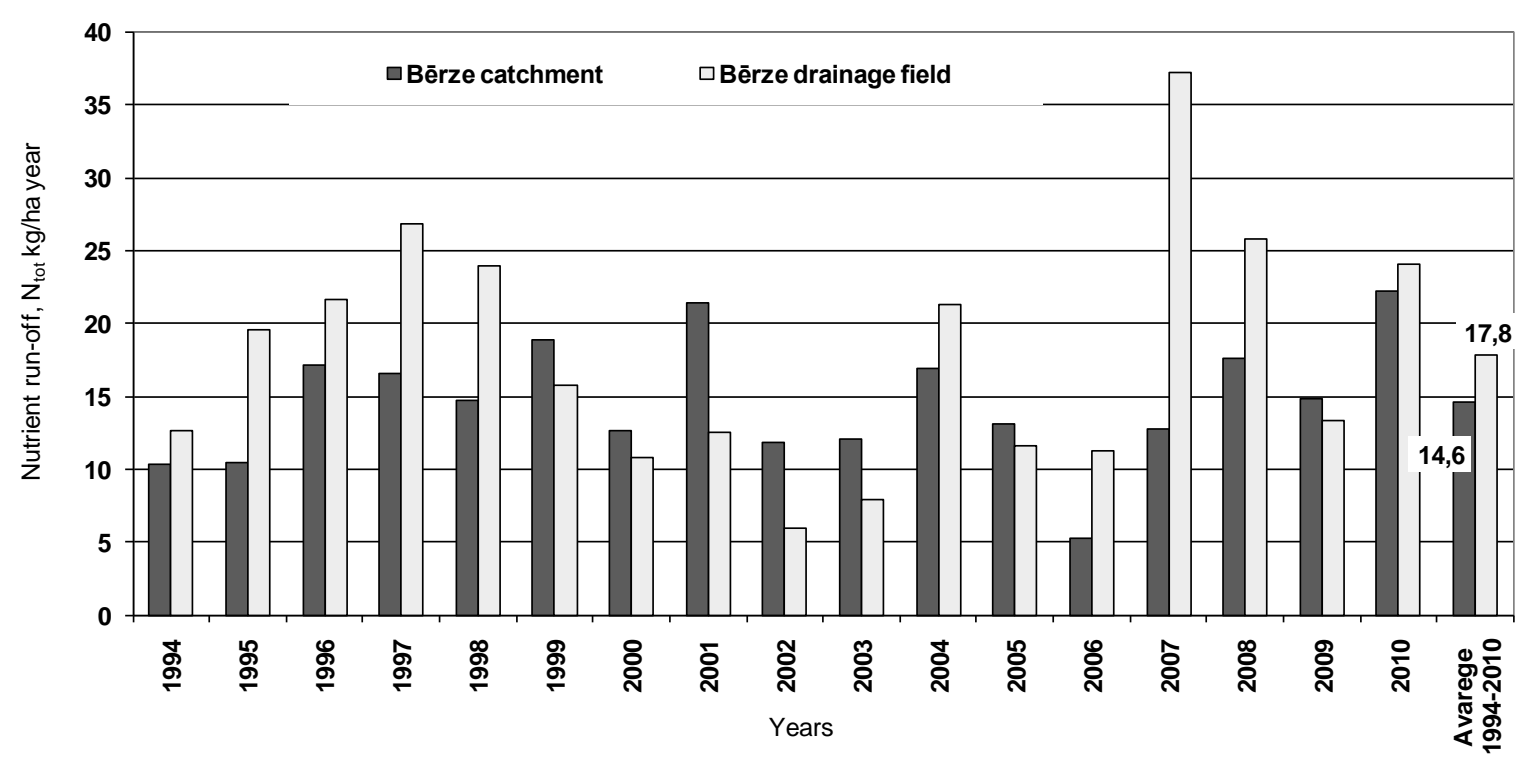

Fig. 9. Nitrogen run-off from diffuse pollution sources, Bērze monitoring station. 


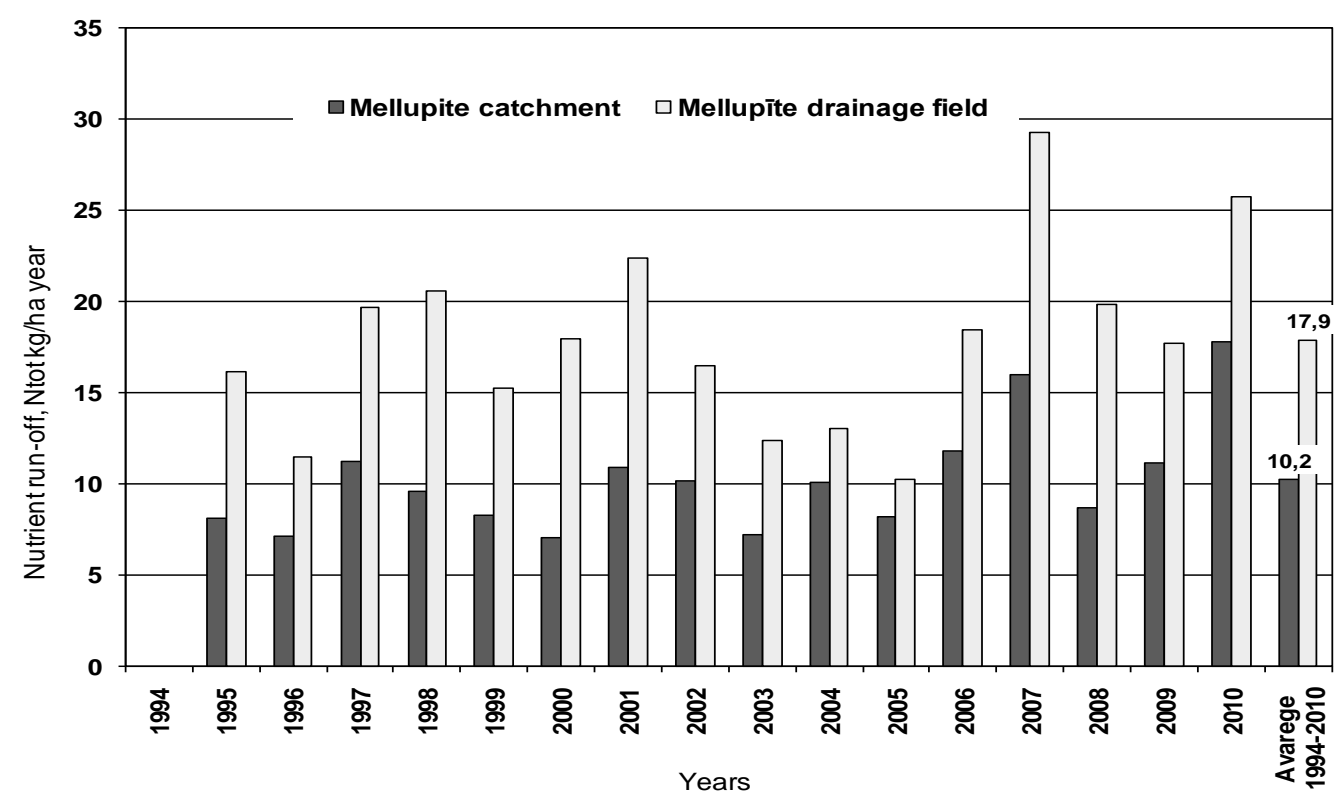

Fig 10. Nitrogen run-off from diffuse pollution sources, Mellupīte monitoring station.

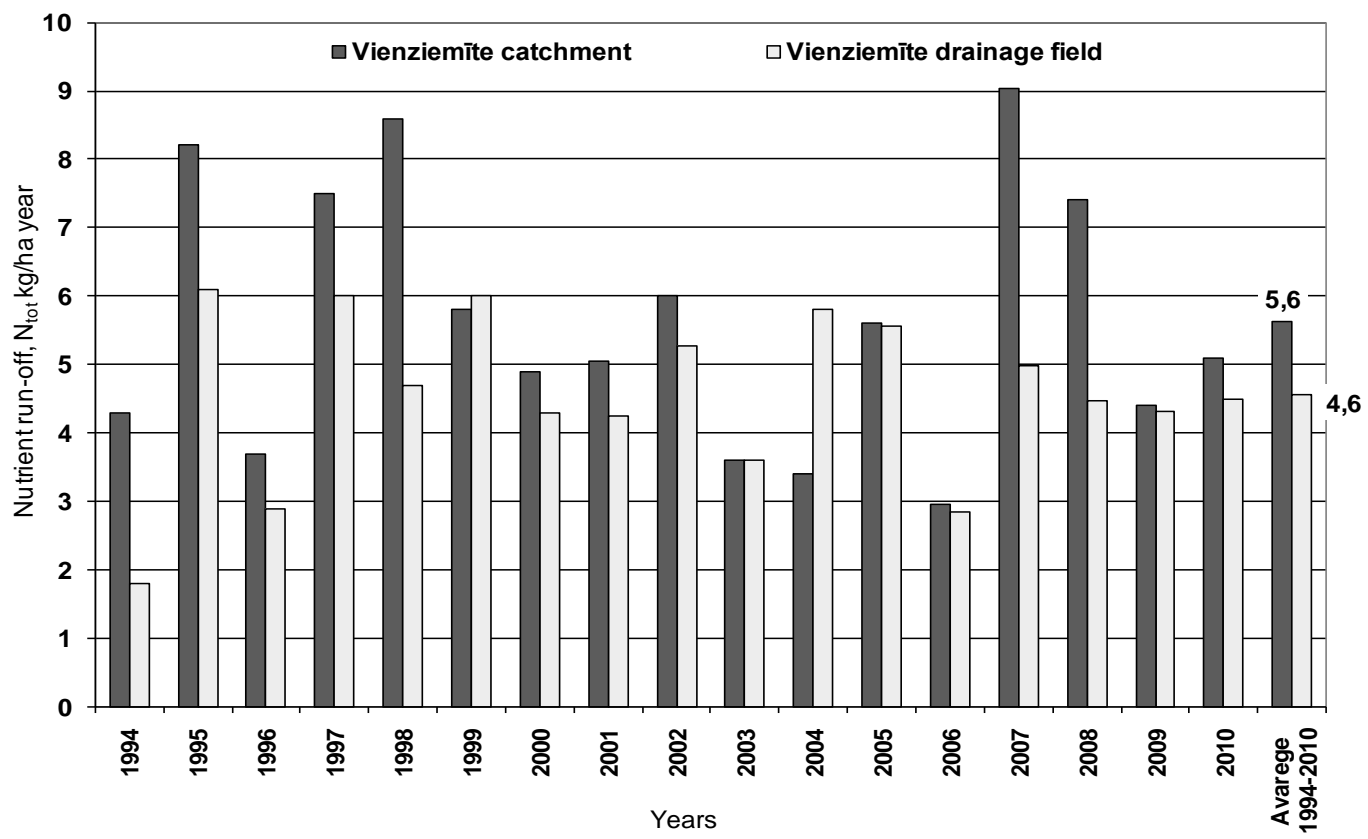

Fig 11. Nitrogen run-off from diffuse pollution sources, Vienziemīte monitoring station.

Our study showed that, compared with diffuse nitrogen pollution, phosphorus run-off has no direct correlation with the intensity of agriculture. In the case of phosphorus, nutrient problems are related to excess precipitation and/or snowmelt which can lead to surface runoff induced erosion and nutrient loss, causing deteriorating water quality in the field drainage and catchment scale. During 1994 to 2010 the highest phosphorus run-off was observed in the Bērze site (Fig. 12 and 13) during the spring flood. 


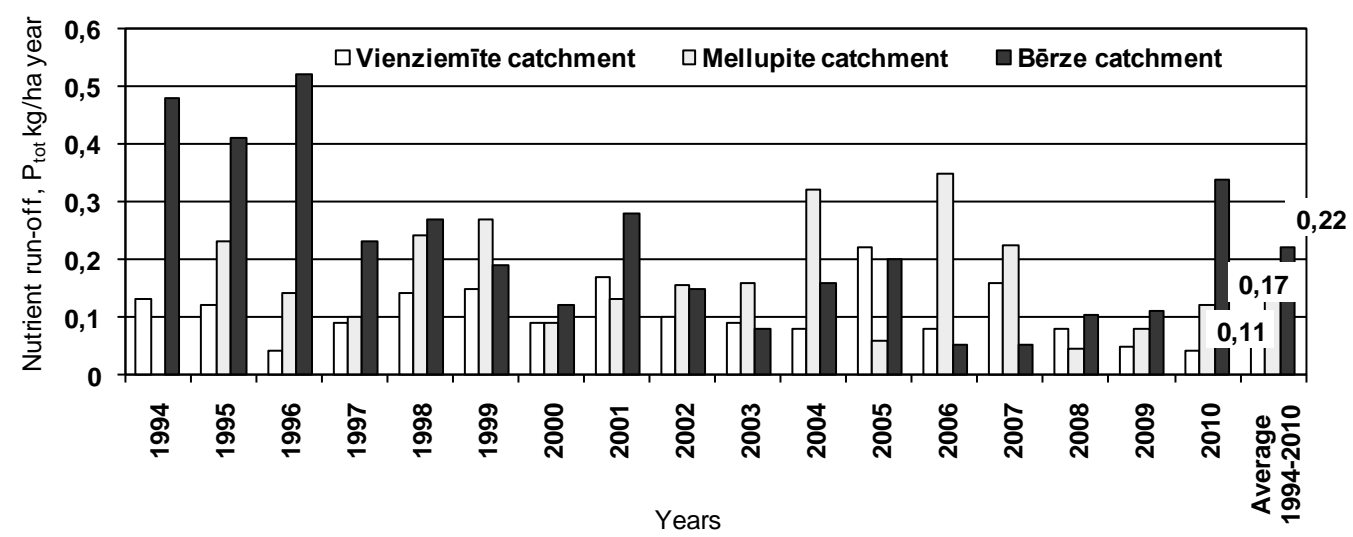

Fig. 12. Phosphorus run-off from diffuse pollution sources in small catchment scale, Bērze, Mellupīte, Vienziemīte monitoring stations.

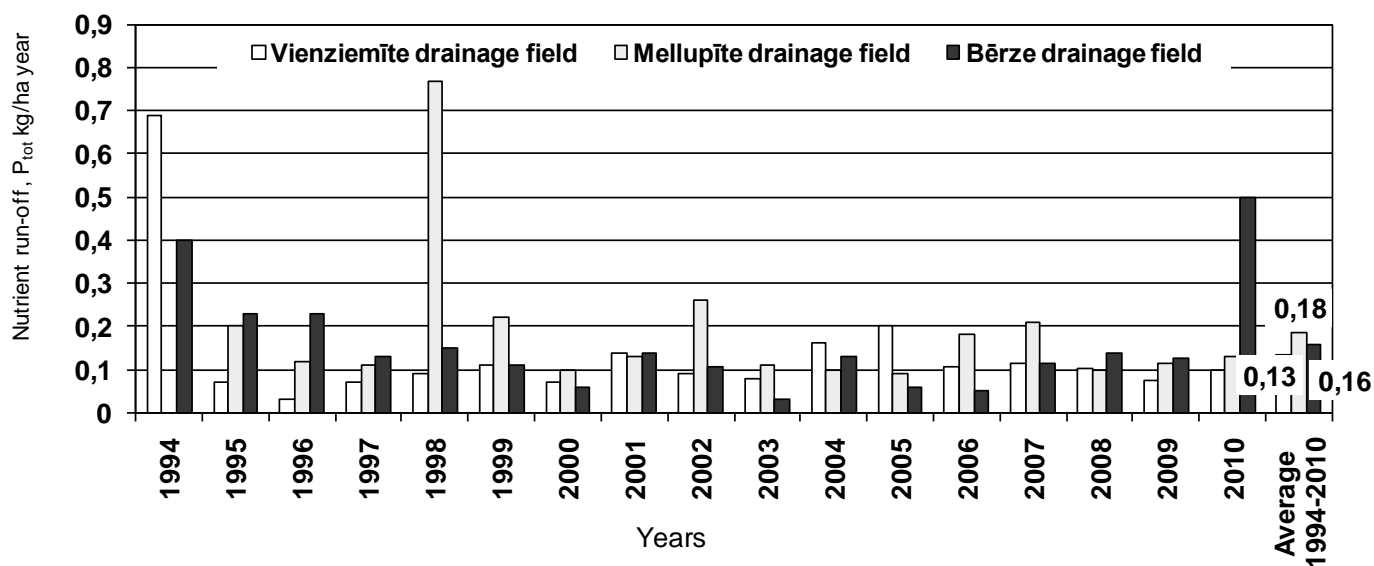

Fig. 13. Phosphorus run-off from diffuse pollution sources in field drainage scale, Bērze, Mellupīte, Vienziemīte monitoring stations.

D. Nutrient run-off in the point source pollution monitoring points

Nutrient run-off from agricultural point sources (animal farm) for the Bauska monitoring point is presented in Fig. 14 and 15. Overloading fields with manure from too many animals or using improper manure handling practices caused an average nitrogen leaching of about 2 times higher ( $49 \mathrm{~kg}$ $\mathrm{ha}^{-1} \mathrm{~N}_{\text {tot }}$ year) than leaching from diffuse pollution catchment. Compared with diffuse pollution catchment, phosphorus runoff was more than 10 times higher, reaching extremely high values (16.9 kg ha ${ }^{-1} \mathrm{P}_{\text {tot }}$ year) in 2009. High phosphorus leaching was still observed in the Ogre farm that was closed in $1992[7,24]$.

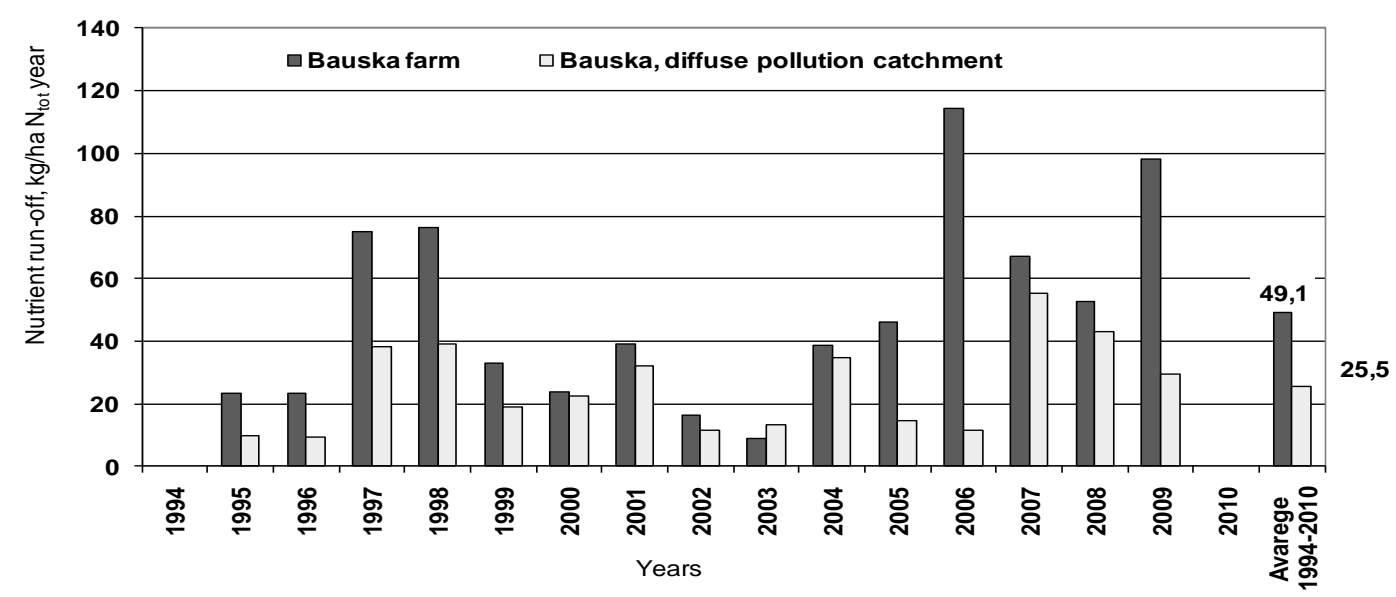

Fig. 14. Nitrogen run-off from point source pollution, Bauska farm monitoring point. 




Fig. 15. Phosphorus run-off from point source pollution, Bauska farm monitoring point.

\section{CONCLUSIONS}

Our research demonstrates how many nutrients may be released into the water environment by leaching in Latvia. It is essential that the relevant monitoring methods and long term monitoring programs are implemented for the assessment of agricultural pollution sources. Due to the climatic conditions, the available data show a high variation in the water quality in both spatial and temporal terms. The total nutrient run-off greatly depends on nutrient concentrations and water discharge, especially in flood periods. On the field drainage scale, nitrate concentrations are often higher than the nitrate limit value set by the Nitrate Directive.

The increased intensity of farming has resulted in an upward trend in both nutrient concentrations and nutrient runoff. Weather-driven hydrology, agricultural land use (acreage of arable land) and fertilizer application are the main factors which impact diffuse source nutrient run-off.

Poor manure handling practices could substantially increase the point source nutrient runoff from agriculture, e.g., as regards to phosphorus leaching, it could be increased more than 10 times, compared with diffuse pollution sources.

National agricultural policy and support measures should integrate agro-environmental requirements to mitigate nutrient pollution of inland water ecosystems.

\section{REFERENCES}

1. Berzina, L., Sudars, R.., Jansons, V.Impact of intensive livestock farming on surface water quality in Latvia. Water Management Engineering, Transactions of the Lithuanian University of Agriculture, water Management Institute of Lithuania. 2008. (34), ISSN 1382-2335, p.106-117.

2. Deelstra, J., Eggestad, H.O., Iital, A., Jansons, V. Hydrology in small agricultural catchments; pathways and their impact on nutrient and soil loss. In: Hermann, A. \& Schumann, S. (Eds). International Workshop on
Status and perspectives of Hydrology in Small basins. Hahnenklee, Germany, 2009. ISBN 978-3-89720-996-1, p. 75 - 79.

3. Deelstra, J., Eggestad, H.O., Iital, A., Jansons, V. \& Barkved L. J. Time resoslution and hydrological characteristics in agricultural catchments. IAHS Publ. 336, 2010. ISBN 978-1-907161-08-7, p. 138 143.

4. Directive 2000/60/EC of the European Parliament and of the Council of 23 October 2000 establishing a framework for Community action in the field of water policy. Official Journal of the European Communities. 22.12.2000. p. L327/1-L327/72.

5. Draft Guidelines for the Monitoring Required under the Nitrates Directive, updated 26/03/2003. Nitrate Commission. Brussels.

6. Iital, A., Pachel, K., Loigu, E., Pihlak, M., and Leisk, U. Recent trends in nutrient concentrations in Estonian rivers as a response to large-scale changes in land-use intensity and life-styles. Journal of Environmental Monitoring. 12 (2010), p. 178-188.

7. Haraldsen,T.K., Jansons, V., Spricis, A., Sudars, V, and Vagstad, N. Influence of long-term heavy applications of pig slurry on soil and water quality in Latvia. In: Towards Sustainable Land Use. Advances in GeoEcology 31. Reiskirchen, Germany. 1998. p. 621-628.

8. Jansons V. (1996). Lauksaimniecības noteču monitorings Latvijāā [Monitoring of agricultural run-off in Latvia]. LLU raksti Nr. 6 (283), Jelgava, 109-115. lpp. (in Latvian).

9. Jansons V., Vagstad N., Deelstra., J. Nutrient losses from agricultural areas in Latvia. In: Agriculture and the Environment. Challenges and Conflicts for New Millenium. Turner, S; Alford, D. (ed.). Proceedings of ADAS conference 14-16 April 1999. University of Warwick, England. p. 83-92.

10. Jansons, V., Vagstad, N., Sudars, R., Deelstra, J., Dzalbe, I., Kirsteina D. Nutrient Losses from Point and Diffuse Agricultural Sources in Latvia. Landbauforschnung Volkenrode. Volume 1, (52/1). 2002.p 9-17.

11. Jansons, V., Busmanis P., Dzalbe I. and Kirsteina D. Catchment and drainage field nitrogen balances and nitrogen loss in three agriculturally influenced Latvian watersheds. European Journal of Agronomy 2003. Volume 20. p.173-179.

12. Jansons, V., Sudars, R., Kḷaviṇš, U. Vides risku vadība lauksaimniecībā. [Management of the Environmental Risk in Agriculture]. In: Monogrāfija: Lauksaimniecības un pārtikas risku vadība. 2007. Jelgava. 494.-503. lpp. (in Latvian). 
13. Jansons, V., Abramenko, K., Timbare, R., A.Lagzdiṇš., Vircavs, V Lauksaimniecības izraisītā nitrātu piesārṇojuma riska analīze Latvijā. (Risk assessment of the agricultural pollution with nitrates in Latvia). Monogrāfija: Lauksaimniecības un pārtikas risku vadība. 2007. Jelgava, ,p.525-543. (in Latvian).

14. Jansons, V., Abramenko, K., Timbare, R., Bērziṇa, L. Risk assessment of the agricultural pollution with nitrates in Latvia. In: Proceedings of Latvia University of Agriculture 2009. No. 22 (316), ISSN 1407-4427. p.1-11.

15. Jansons, V., Sudars, R. Dimensions of Agri-Environmental Research in the Department of Environmental Engineering and Water Management. In: Proceedings of the International Scientific Conference. Latvia University of Agriculture - 70. 2009. ISBN 978-9984-48-007-7, Jelgava. p. $47-58$.

16. Krams, M., Ziverts, A. 1993. Experiment of conceptual mathematical ground water dynamics and run-off modeling in Latvia. Nordic Hydrology, vol.24, No.4.

17. Lagzdiņš, A., Jansons, V., Abramenko, K. Setting of the Water Quality Standards for Nutrients in Runoff from Agricultural Land (Ūdeņu kvalitātes standarta noteikšana pēc biogēno elementu koncentrācijas notecē no lauksaimniecībā izmantotajām platībām). LLU Raksti 21 (315), 2008; p. 96-105 (in Latvian).

18. Lagzdins, A., Jansons V. Application of Statistical Methods for Analysis of Agricultural Runoff Monitoring Data. Scientific Journal of Riga Tehnical University: Environmental and Climate Tehnologies, 2010. Series 13, Vol. 5, ISSN 1691-5208, p. 65-71.

19. Lauksaimniecības noteču (noplūdes) monitoringa rokasgrāmata. [Quidelines for monitoring of agriculural run-off] LVA . 2003. 34. lpp. LVĢMC mājas lapa http://www.meteo.lv/public/27998.html, (in Latvian)

20. LR MK noteikumi Nr. 92. (ar groz. 27.01.2009.) Prasības virszemes ūdenu, pazemes ūdenu un aizsargājamo teritoriju monitoringam un monitoringa programmu izstrādei

21. LR MK noteikumi Nr. 33. "Par ūdens un augsnes aizsardzību no lauksaimnieciskās darbības izraisītā piesārņojuma ar nitrātiem” (2011.gada 11.janvārī.).

22. Nitrate Directive No 91/676/EEC of 12 December 1991 concerning the protection of waters against pollution caused by nitrates from agricultural sources. Official Journal of the European Communities. 31.12.91. p. L375/1-L375/8.

23. Stalnacke P., Vagstad N., Tamminen T., Wassmann P., Jansons V, and Loigu E. Nutrient runoff and transfer from land and rivers to the Gulf of Riga. Hydrobiologia 410. 1999. p.103-110.

24. Sudars, R., Jansons, V., Kḷaviňš, U., Dzalbe, I.. Intensīvas lopkopības ietekme uz ūdens vidi [Impact of the intense animal farming on water environment]. Latvijas Lauksaimniecības universitātes raksti. $\mathrm{Nr} 15$ (310), 2005. Jelgava. 40. - 49. lpp. (in Latvian).

25. Vagstad, N., Jansons, V., Loigu, E., and Deelstra. Nutrient losses from agricultural areas in the Gulf of Riga drainage basin. Ecological Engineering, 14, 2000. p. 435-441.

26. Vagstad N., Stalnacke P., Andersen, H.E., Deelstra, J., Gustafson, A., Ital, A., Jansons, V., Kyllmar, K., Loigu, E. and Rekolainen, S. Nutrient Losses from Agriculture in the Nordic and Baltic Countries. TemaNord 2001: 591. Nordic Council of Ministers, 2001. Copenhagen, ISSN 0908-6692. p.74.

27. Vagstad, N., Stalnacke, P., Andersen, H.E., Deelstra, J., Jansons, V., Kyllmar, K., Loigu, E., Rekolainen, S. and Tumas, R. Regiona variations in diffuse nitrogen losses from agriculture in the Nordic and Baltic regions. Hydrology and Earth System Sciences, 8 (4). 2004. p. 651-662.

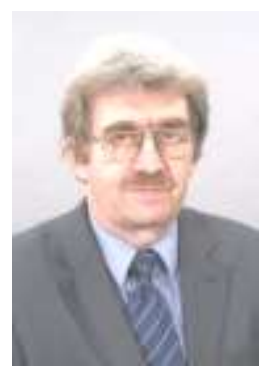

Viesturs Jansons, Dr.sc.ing., professor, Faculty of Rural Engineering, Latvia University of Agriculture. V.Jansons is a member of academic staff of the Department of Environmental Engineering and Water Management since 1975. He has an experience of 17 years in monitoring and assessment of impact of agriculture on surface water quality, monitoring of the agricultural run-off (nonpoint pollution) in different geographical scales. Since 1994, he has been involved in many national and international projects (BEAROP, Gulf of Riga and BSRP) concerning impact of agricultural pollution sources on inland water quality in Latvia. He represented Latvia in HELCOM PITF/TC WG on Agriculture and HELCOM TFSA for BA21 in the Agricultural Sector. He was member (2004-2006) of Environment Security panel of NATO Science for Peace Programme. As a teacher, besides LLU courses, he is involved in Baltic University programme and NOVABOVA MSc and PhD courses.

Address: 19 Akademijas Street, Jelgava, LV-3001

Phone: +37163029851



E-mail: viesturs.jansons@1lu.lv

Ainis Lagzdins, Mg.sc.ing., lecturer, Faculty of Rural Engineering, Latvia University of Agriculture. A. Lagzdins started to work as academic staff in the Department of Environmental Engineering and Water Management, Latvia University of Agriculture in 2005. He has Bachelor's degree in Environmental Science (2004) and Master's degree in Environmental Engineering (2006). Since 2006 he is a doctoral student of study program „Environmental Engineering”. The theme of $\mathrm{PhD}$ thesis is ,Analysis of the water quality concerning nutrients in the agricultural runoff'. The main research topics are water quality of agricultural runoff in different agro-climatic regions of Latvia and modeling of the water quality and quantity. A. Lagzdins has been involved in several national and Nordic/Baltic cooperation projects on assessment and modeling of nutrients leakage.

Address: 19 Akademijas Street, LV-3001, Jelgava, Latvia

Phone: +371 63029851

E-mail: ainis.lagzdins@1lu.lv



Ritvars Sudars, Dr.sc.ing., professor, Faculty of Rural Engineering, Latvia University of Agriculture. R.Sudars is a part of academic staff of the Department of Environmental Engineering and Water Management since 1981 and dean of Faculty of Rural Engineering since 2002. The main research area is point source nutrient run-off from agricultural areas for slurry utilisation. PhD thesis "Influence of slurry application on the water quality in Latvia" was defended in Latvia University of Agriculture (1998). He has participated in different local and international projects related to the agricultural run-off, as well as he is author of more than 40 publications. Adress: 19 Akademijas Street, Jelgava, LV-3001

Phone: + 37163027709

E-mail: Ritvars.sudars@1lu.lv

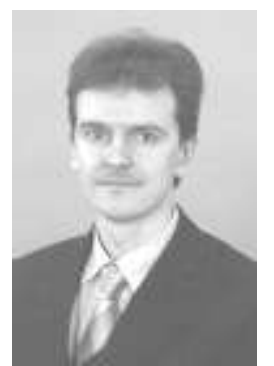

Kaspars Abramenko, Mg.sc.ing., lecturer, Faculty of Rural Engineering, Latvia University of Agriculture. Since 2000 he is among the academic staff in the Department of Environmental Engineering and Water Management. In 2002 he graduated MSc studies on Environmental Engineering Science. Experience of 13 years research in agricultural impact assessment on water bodies and water quality modeling is connected to his $\mathrm{PhD}$ thesis "Agricultural diffuse source pollution in Latvia". He mainly deals with multi scale agricultural run-off monitoring data collection in Latvia to estimate pollution source apportionment within river basins. As a scientist he is involved in national water monitoring programmes and international research projects BEAROP, BSRP, COST, RECOCA concerning nutrient losses from agricultural land. Since 2010 he participates in the ESF project „Establishment of interdisciplinary scientist group and modeling system for groundwater research".

Address: 19 Akademijas Street, LV-3001, Jelgava, Latvia

Phone: +37163029908

E-mail: kaspars.abramenko@1lu.lv

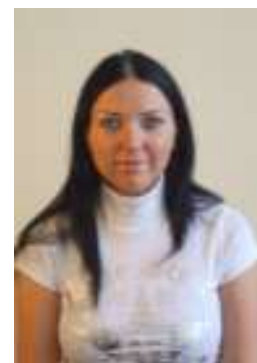

Laima Berzina, Mg.Sc., lecturer, Latvia University of Agriculture, Department of Environmental Engineering and Water management since 2008. Laima Berzina is also a part of academic staff of Faculty of Information Technologies, Latvia University of Agriculture since 2001. The main research area is point source water pollution from agricultural sources and statistical analysis of 
environmental pollution. She has participated in several local projects, international and local conferences related to environmental pollution risk analysis. She is writing $\mathrm{PhD}$ thesis "Point Source Water Pollution from Agricultural Activities in Nitrate Vulnerable Zones".

Address: Liela street 2, LV-3001, Riga, Latvia

Phone: +37163029908

Viesturs Jansons, Ainis Lagzdiṇš, Laima Bērziṇa, Ritvars Sudars, Kaspars Abramenko. Augu barības vielu izskalošanās no lauksaimniecības zemēm Latvijā mainība laikā un telpā: Noplūdes un aiztures ilggadīgie trendi mazos sateces baseinos un drenu sistēmās

Lauksaimniecība var izsaukt paaugstinātu ūdeņu vides piesārṇojumu. LLU uzsāka lauksaimniecības piesārņojuma monitoringu 1994.g., izveidojot monitoringa sistēmu lauksaimniecības difūzā un punktveida piesārnojuma noteikšanai. Augu barības elementi - slāpekḷa un fosfora savienojumi ūdenos var nonākt no dažāda rakstura piesārṇotājiem. Difūzais piesārṇojums dod galveno slāpekḷa piesārņojuma daļu Latvijas virszemes ūdeņos. Difūzais piesārṇojums ar slāpekḷa un fosfora savienojumiem eksistē vienmēr un visur, to var tikai daḷeji samazināt ar agro-vides pasākumiem. Punktveida piesārṇojums lauksaimniecībā saistîts ar nesakārtotu kūtsmēslu saimniecību lielajās lopkopības fermās. Parasti lauksaimniecības intensifikācija un šaura specializācija noved pie paaugstinātas vides piesārnošanas, kuras novēršanai vajadz̄̄gie finanšu resursi var būt lielāki, kā īslaicīgais ieguvums no ražošanas intensifikācijas. ES un Latvijas likumdošanas akti prasa kontrolēt lauksaimniecības ietekmi uz ūdens vidi, lai samazinātu piesārnojumu ar slāpekli un citiem biogēniem elementiem. Darbā apskatīti ilggadīga (1994.g. - 2010.g.) lauksaimniecības piesārņojuma monitoringa rezultāti, kas parāda, ka nitrātu slāpekḷa koncentrācijas ir atkarīgas no monitoringa sistēmas līmeņa (drenu lauks, mazais sateces baseins) un lauksaimnieciskās ražošanas intensitātes. Izmantojot ilggadīgās datu rindas, novērtēta biogēno elementu koncentrāciju mainība un atškirības drenētos laukos un mazos sateces baseinos. Mazo sateces baseinu līmenī nitrātu robežvērtība visbiežāk tiek pārsniegta Bērzes monitoringa stacijā, platībās ar intensīvu lauksaimniecību. Ilggadīgi novēroto (1994. - 2010.g.) slāpekḷa savienojumu trendu analīze uzrāda koncentrāciju pieaugumu Bērzes un Mellupītes stacijās un nenozīmīgas izmainas Vienziemītes stacijā. Bērzes monitoringa stacijā, intensīvas lauksaimnieciskās ražošanas apstākḷos, atseviškos gadījumos (ziemas periods) nitrātu koncentrācijas ievērojami pārsniedza Nitrātu direktīvas noteiktos robežlielumus. Vienziemītes stacijā (ekstensīva lauksaimniecība) slāpekḷa koncentrācijas ir zemas un tuvas dabiski tīriem ūden̦iem. Augstākās slāpekḷa un, it sevišķi, ūdeṇu ekosistēmām bīstamā fosfora koncentrācijas novērotas punktveida piesārṇojuma monitoringa posteņos Bauskā un Ogrē.

Виестурс Янсонс, Айнис Лагздиныш, Лаима Берзиня, Ритварс Сударс, Каспарс Абраменко. Изменения во времени и территории вимивания питательных веществ растений из сельхозугодий в Латвии: Многолетные тренды выноса и задержки в басейнах малого водозабора и в дренажных системах

Сельское хозяйство может способствовать повишенному загрязнению водной среды. ЛСХУ начала мониторинг сельскохозяйственного стока в 1994 году, создавая в Латвии систему мониторинга для определения диффузного и точечного загрязнения от сельского хозяйства. Питательные вещества растений - соединения азота и фосфора поступают в водные объекты от загрязнителей разного характера. Диффузное загрязнение дает основную часть загрязнения азотными соединениями, поступающими в поверхностные воды. Диффузное загрязнение азотом и фосфором существует всегда и везде, его можно только уменьшить мероприятиями по защите агросреды. Точечное загрязнение от сельского хозяйства связано с неполадками в применении органического удобрения в больших животноводческих фермах. Как правило, интенсификация сельского хозяйства и узкая специализация приводит к повышенному загрязнению среды, для устранения которого понадобятся большие финансовые ресурсы, чем временная польза от интенсификации производства. Нормы законодательства ЕС и Латвии для снижения загрязнения азотом и другими биогенными элементами, требуют установить контроль влияния сельского хозяйства на водную среду. В работе приводятся результаты многолетнего (1994 - 2010 гг.) мониторинга загрязнения от сельского хозяйства, которые показывают, что концентрации нитратного азота зависят от уровня мониторинга (бассейн малого водозабора и дренажная система) и уровня интенсификации производства. Используя данные многолетних наблюдений, оценены изменения концентрации биогенных элементов и их различия в бассейнах малого водозабора и в дренажных системах. В бассейнах малого водозабора предельные концентрации нитратного азота часто превышаются на станции мониторинга «Ве̄rze», в угодиях с интенсивнным сельским хозяйством. Анализ трендов многолетних наблюдений (1994 - 2010 гг.) показывают прирост концентрации на станциях мониторинга «Ве̄ге» и «Меllupīte» и незначительные изменения в «Vienziemīte». На станции мониторинга «Bērze», в условиях интенсивного сельскохозяйственного производства, в отдельных случаях (зимний период) концентрации нитратного азота существенно превышали предельные концентрации, установленные Нитратной Директивой. На станции «Vienziemīte» (экстенсивное сельское хозяйство) концентрации нитратного азота низкие и близки к фоновой концентрации природных вод. Самые высокие концентрации азота и особенно опасного для водных экосистем соединений фосфора наблюдались в постах мониторинга точечного загрязнения Bauska и Ogre. 